Proceedings

\title{
Structure of the Stridulatory Apparatus of Some Species Heteroceridae (Coleoptera) ${ }^{\dagger}$
}

\author{
Elena Yu. Rodionova ${ }^{1, *}$, Alexey S. Sazhnev ${ }^{2, *}$, Alexey A. Miroliubov ${ }^{3}$, Semen Yu. Kustov ${ }^{1}$ \\ 1 Department of Zoology, Kuban State University, Stavropolskaya Street, 149, 350040 Krasnoda, Russia; ri- \\ gaey@gmail.com (E.Yu.R.); kustov-semen@mail.ru (S.Yu.K.) \\ 2 Papanin Institute for Biology of Inland Waters, Russian Academy of Sciences, Borok 109, Nekouz District, \\ Yaroslavl Region, 152742 Russia; sazh@list.ru \\ 3 Laboratory of Parasitic Worms and Protists, Zoological Institute of the Russian Academy of Sciences, Saint- \\ Petersburg, Russia; Alexei.Miroljubov@zin.ru \\ * Correspondence: rigaey@gmail.com (E.Yu.R); sazh@list.ru (A.S.S.) \\ + Presented at the 1st International Electronic Conference on Entomology (IECE 2021), 1-15 July 2021; \\ Available online: https://iece.sciforum.net/.
}

Citation: Rodionova, E.Y.; Sazhnev A.S.; Miroliubov, A.A.; Kustov, S.Y. Structure of the Stridulatory Apparatus of Some Species Heteroceridae (Coleoptera), in Proceedings of the 1st International Electronic Conference on Entomology, 1-15 July 2021, MDPI: Basel, Switzerland, doi:10.3390/IECE-10911

Published: 30 October 2021

Publisher's Note: MDPI stays neutral with regard to jurisdictional claims in published maps and institutional affiliations.

Copyright: (C) 2021 by the authors. Submitted for possible open access publication under the terms and conditions of the Creative Commons Attribution (CC BY) license (http://creativecommons.org/licenses /by/4.0/).

\begin{abstract}
The variegated mud-loving beetles use an acoustic channel to communicate each other. They produce sound by scarping hindleg plectrum over stridulatory file. This study explores, for the first-time difference on these structure for Augyles and Heterocerus. The research is based on image the sound-producing structures on scanning electron microscope. We measured next parameters: the size of stridulatory file on $100 \mu \mathrm{m}$, number of ridges on $50 \mu \mathrm{m}$ and the size of plectrum. This paper has demonstrated how these parameters depend on each other for 15 species and the stridulatory organ is vary between male and female (Augyles genus).
\end{abstract}

Keywords: the variegated mud-loving beetles; stridulatory organs; plectrum; scanning electron microscope

\section{Introduction}

The family Heteroceridae MacLeay, 1825 (Coleoptera) or variegated mud-loving beetles are wide-spread in the world. The world fauna of Heteroceridae, totals 364 species (pers. data); previous estimates ranged from 320-370 species [1, 2], because the fauna has not been revised. In general, species of the family Heteroceridae occur in temperate, subtropical, and tropical latitudes. Heterocerids have evolved in the unstable habitats of water-land ecotones and show high taxonomic diversity and abundance in semiaquatic communities. Adults and larva of Heteroceridae construct branched networks of tunnels and chambers in a moist soft substrate, which are used for feeding, egg laying and pupation [3]. At high densities with another stratobionts they give a specific microrelief for substrate [4]. The imago often flies to-ward lights (LED's, vapor mercury lamps) at night [5], it can be used as a collection method.

Species of the family Heteroceridae prefer finely dispersed clay and sand types of soil with sufficient moisture, on which colonies are often formed with pronounced biotopic sympatry (cohabitation of species). The variegated mud-loving beetles use an acoustic channel to communicate each over. They produce sound by scraping hindleg ridge (plectrum) over first abdominal ridge (stridulatory file) [6]. The stridulatory file is varied for different genus. For genus Augyles Schiödte, 1866 the stridulatory file forms are a complete; for genus Heterocerus Fabricius, 1792 stridulatory file is an incomplete [7, 8]. Some articles shows that male and female have different number of ridges: males have more strongly developed ridges and females ridges smoother or with small creases $[9,10]$, it may be related to sexual behavior. The main works on systematic of family Heteroceridae describes characteristics, such as male genitalia, the basic color pattern of the body, the 
humeral angle, types of fascia, the pronotum anterolateral angel etc. [11-15]. Now, modern methods of microscopy allow investigating new features of morphology. And our research shown differences on structure of the hindleg ridge (plectrum) and the stridulatory files for Augyles and Heterocerus for the first time. The structure of the stridulatory apparatus can vary for this genus and shows difference between species and between sexes.

\section{Material and methods}

\subsection{Morphology}

To image the sound-producing structures in males and females, beetles were prepared for scanning electron microscopy by separating the abdomen and the posterior leg from the rest of the body. Specimens were mounted on aluminum stubs and coated with palladium (Ion coater IB-5, Eiko Engineering Co., Ltd., Japan) prior to imaging using a variable pressure scanning electron microscope (Hitachi TM-1000, Hitachi, Japan) at Zoology Institute of Russian Academy of Science.

\subsection{Characteristics of the structure of stridulatory file and plectrum}

The present study has only explored 17 specimens and 15 species. Only two species have male and female specimens. For measurements of stridulatory file of the thirst abdominal segment and plectrum of the posterior femur we used Image Pro (Media Cybernetics, USA). We measurements the following parameters for stridulatory file: the size of stridulatory file on $100 \mu \mathrm{m}$, the number of ridges on $50 \mu \mathrm{m}$. For the plectrum we measurements the size of plectrum.

\section{Results and Discussion}

The result of measurements different parameters of morphology structure the stridulatory apparatus shown variation between male and female structure (Augyles genus). Also, we can see correlation between the size of plectrum and the size of stridulatory file. The results of these measurements are presented in Table 1.

Table 1. The different parameters of stridulatory apparatus of Heteroceridae.

\begin{tabular}{|c|c|c|c|}
\hline Species & $\begin{array}{c}\text { size of } \\
\text { stridulatory } \\
\text { file }(\mu \mathrm{m})\end{array}$ & $\begin{array}{c}\text { number of } \\
\text { ridges }(\mu \mathrm{m})\end{array}$ & $\begin{array}{c}\text { size of } \\
\text { plectrum }(\mu \mathrm{m})\end{array}$ \\
\hline Augyles delutissimus (Reitter, 1887) 우 & 408.62 & 19 & 441.43 \\
\hline A. delutissimus (Reitter, 1887) 0 & 417.71 & 17 & 366.99 \\
\hline A. flavidus (Rossi, 1794) & 383.19 & 53 & - \\
\hline A. hispidulus (Kiesenwetter, 1843) 우 & 413.33 & 19 & 455.22 \\
\hline A. interspidulus (Charpentier, 1979) 우 & 390.00 & 17 & 423.70 \\
\hline 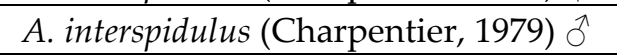 & 434.86 & 16 & 408.72 \\
\hline A. obliteratus Kiesenwetter, 1843 & - & 19 & 517.80 \\
\hline A. turanicus (Reitter, 1887) & 411.76 & 25 & 385.34 \\
\hline Heterocerus fenestratus (Thunberg, 1784) & 431.80 & 21 & 389.21 \\
\hline H. flexosus, Stephens, 1829 & 426.51 & 25 & - \\
\hline H. fossor Kiesenwetter, 1843 q & 475.89 & 17 & 518.18 \\
\hline H. fusculus Kiesenwetter, 1843 & 369.23 & 30 & 322.27 \\
\hline H. heydeni Kuwert, 1890 ㅇ & 468.33 & 20 & - \\
\hline H. kaszabi n. sb. & 475.06 & 22 & - \\
\hline H. marginatus (Fabricius, 1787) & 392.09 & 24 & 416.42 \\
\hline H. obsoletus Curtis, 1828 & 328.91 & 20 & 574.00 \\
\hline H. parallelism Gebler, 1830 ㅇ & 399.76 & 15 & 505.59 \\
\hline
\end{tabular}


Comparing males and females of Augyles delutissimus and Augyles interspidulus, we concluded that the size of the stridulation file in males is larger than in females. At the same time, the number of teeth less. Also, the size of the plectrum is much smaller for males. The size of plectrum for females of A. delutissimus and A. interspidulus is $441.43 \mu \mathrm{m}$ and $423.70 \mu \mathrm{m}$ against $366.99 \mu \mathrm{m}$ and $408.72 \mu \mathrm{m}$ for males of these species. The size of the stridulatory file for species of Augyles are vary from $383.19 \mu \mathrm{m}$ (A. flavidus) to $434.86 \mu \mathrm{m}$ (A. interspidulus). But the number of ridges has the inverse proportionality of the size of stridulatory file. The maximum number is 53 for A. flavidus and 16 for A. interspidulus.

The stridulatory file of Heterocerus genus is varied from $328.91 \mu \mathrm{m}$ (H. obsoletus) to $475.89 \mu \mathrm{m}(H$. fossor). H. fusculus has the largest number of ridges (30) and the smallest size of plectrum $(322.27 \mu \mathrm{m})$. H. parallelism has 15 number of ridges, and the size of stridulatory file is $399.76 \mu \mathrm{m}$. H. obsoletus has the largest size of plectrum $(574.00 \mu \mathrm{m})$.

\section{Conclusion}

The results of this study show that structure of the stridulatory organ is vary between male and female (Augyles genus). Almost all cases the number of ridges has the inverse proportionality of the size of stridulatory file. And the same time the size of plectrum has the same relation. Future research is needed to investigate large specimens' group for each species (male and female). These studied will help us understand the difference at structure of stridulatory organs different species and between sexes within species. Future studies will focus on comparing the morphology of the stridulatory structure with the sound characteristics imago.

Author Contributions: methodology R.E.Yu., S.A.S and M.A.A.; writing-original draft preparation R.E.Yu. and S.A.S.; formal analysis R.E.Yu. and S.A.S.; data curation S.A.S.; funding acquisition K.S.Yu.

Funding: The reported study was funded by RFBR according to the research project №20-34-90022. This work was supported by budget funding (projects 121051100109-1) of the Russian Academy of Sciences

Institutional Review Board Statement: Not applicable.

Informed Consent Statement: Not applicable.

Data Availability Statement: Data are available on request from the corresponding authors.

Acknowledgments: Confocal microscopy was performed at the "Taxon" Research Resource Centre (Zoological Institute, Russian Academy of Sciences) (http://www.ckp-rf.ru/ckp/3038/).

Conflicts of Interest: The authors declare no conflict of interest.

\section{References}

1. Mascagni A. The Variegated Mud-Loving Beetles of Europe (first part) (Coleoptera: Heteroceridae). Onychium 2014, 10, 78-118.

2. Skalický S., Ezer E. Coleoptera: Heteroceridae. Folia Heyrovskyana. Icones Insectorum Europae Centralis. Series B $2014,18,1-13$.

3. Ratcliffe B.C., Fagerstorm J.A. Invertebrate lebensspuren of Holocene floodplains: their morthology, origin and paleoecological significance, Journal of Paleontology 1980, 54(3), 614-630.

4. Sazhnev A.S. Beetles of the family Heteroceridae (Insecta: Coleoptera) in extreme environments. Ecosystem Transformation 2020, 3(2), 22-31, doi:10.23859/estr-200323a

5. Sazhnev A.S., Rodionova E.Yu. The beetles (Insects: Coleoptera) collected by the light traps with super bright LEDs on the territory of Krasnodar. Izv. Saratov Univ. (N. S.), Ser. Che mistry. Biology. Eco logy 2019, 19(2), 188-195, (in Russian), doi:10.18500/1816-9775-2019-19-2-188-195

6. Schiödte J.C. On the Tunneling Coleopterous Genera Bledius, Heterocerus, Dyschirius, and their Danish Species. In The annals and magazine of natural history including zoology, botany, and geology, 3rd ed.; Babington C.C., Gray J.E., Francis W.; Taylor and Francis: London, 1867; Vol. 22, p. 37.

7. Aguilera P., Mascagni A., Ribera 1., The family Heteroceridae MacLeay, 1825 (Coleoptera, Dryopoidea) in the lberian peninsula and the Balearic Islands. Misc. Zool. 1998, 21(l), 75-100.

8. Stals, R. Heteroceridae. In Guides to the Freshwater Invertebrates of Southern Africa; Stals R., de Moor I.J. Eds.; Struik Nature: Cape Town, South Africa, 2007; Volume 10, p. 163. 
9. Litovkin S.V., Sazhnev A.S., Čiamor F. Jr. Validation of Heterocerus heydeni Kuwert, 1890 based on morphology and DNA barcoding, with notes on the problems of classification of the Heteroceridae (Coleoptera). Zootaxa. 2019, 4614(1), 160-172, doi: 10.11646/zootaxa.4614.1.7

10. Key to Saskatchewan Species of Heteroceridae. Entomological Society of Saskatchewan. Available online: http://www.entsocsask.ca/insect lists.html (accessed on 29.05.2021).

11. Arnett, R.H. 1963. The beetles of the United States. Catholic University of America Press, Washington. 1112 pp.

12. Charpentier R. 1968. A monograph of the family Heteroceridae (Coleoptera) of the Notogean Region. Arkiv für Zoologie 1968, 20, $205-241$.

13. King, J.G., P.K. Lago. The variegated mud-loving beetles (Coleoptera: Heteroceridae) of Mississippi and Alabama with discussion and keys to species occurring in south-eastern United States. Insecta Mundi 2012, 275, 1 - 53.

14. Miller W.V. Heteroceridae. In The beetles of northeastern North America. Downie N.M., Arnett R.H. Eds. Sandhill Crane Press: Gainesville, FL., 1996; Volume 1, pp. 723-726.

15. Pacheco, F. 1964. Sistematica, filogenia y distribucion de los Heteroceridos de America (Coleoptera; Heteroceridae). Monografias del Colegio de Post-graduados; Escxuela Nacionial de Agricultura: Chapingo, Mexico, 1964, Volume 1; 1-155. 